\title{
The Philosophy Basis Of Educational Technology
}

\author{
Ayu Mustika Sari ${ }^{1)}$, Jamaris Jamna ${ }^{2 *}$ \\ 1) Program Studi Doktor Ilmu Pendidikan Pascasarjana Universitas Negeri Padang \\ 2) Universitas Negeri Padang \\ *Coresponding Author \\ Email : ayumustikasari10@gmail.com
}

\begin{abstract}
Philosophy is a general theory of education. In other words, it can be deemed as a very important basis for how education is carried out, so that the goals of education are fully achieved. This is the background why an educational technology science has a philosophical foundation. Educational technology as a scientific discipline has a philosophical foundation that can be studied on educational technology that meets three philosophical studies, which are ontology, epistemology, and axiology. Based on insights retrieved from this article, it is stated that the philosophical foundation of educational technology concerning its ontology is a field of scientific study. Meanwhile, if we look at the etymology of educational technology, it is an approach used in a science. When it is viewed from an axiological point of view, educational technology emphasizes on its benefits, both in general and in particular, directly, physically and abstractly..
\end{abstract}

Keywords: Philosophical Foundations, Educational Technology

\section{INTRODUCTION}

Educational demands are currently growing rapidly. It is in accordance with the dynamics of education in our country, Indonesia, which stems from the 1945 Constitution and Law no. 20 of 2003 which are taken from religious, cultural values. It is also responsive to the demands of a very advanced era, especially in the modern era in terms of development of science and technology.

Education is the main key to human development and the community of a particular nation. Therefore, certain foundations and principles are needed in determining the direction and goals of our education in Indonesia. Some educational foundations that play an important role in determining educational goals are philosophical foundations. Furthermore, educational technology will encourage education to face the future. Education is a series of processes to improve, improve, and change one's knowledge, skills, attitudes and behavior in an effort to educate humans through teaching and training activities. The process shows the existence of activity in the form of active action where there is a dynamic interaction and it is carried out consciously in an effort to achieve the goal.

Improving the quality of learning must be carried out continuously. The needs for educational action must be consciously planned so that changes and better behavior occur. Education is also a field of science. As with other sciences, education is born from its parent, namely philosophy. In line with the development process of science, education science is also slowly separated from its parent. In essence, philosophy is created by humans for the benefit of understanding the position of humans, human development and the improvement of human life. In the process of implementation, both theoretically and practically, education really needs a foundation or pedestal to stand on. This is because education will never succeed optimally without a goal, while the goal will never be achieved and directed without a strong foundation 
or basis. One of the foundations that is often used in an educational institution is the philosophical foundation, which is closely related to the nature or meaning of education. In this case, philosophy is used as a tool to become a foundation for education. In this case, there are three philosophical studies that we can understand, namely ontology, epistemology, and axiology. But in this case, we will focus more on understanding the philosophical foundation of education? The object of the philosophical foundation of educational technology.

\section{RESEARCH METHODS}

This study employs a library method or approach (library research), Literature study or literature can be interpreted as a series of activities, which are collecting library data, reading and recording and processing research's materials (Zed, 2003:3).

In literature research, there are at least four main characteristics that the author needs to pay attention to, among others: First, the researcher is dealing directly with the text or numerical data, not with direct knowledge from the field. Second, library data is "ready to use", meaning that the researcher does not go directly to the field because the researcher is dealing directly with data sources in the library. Third, the library data is generally a source of secondary, in the sense that the researcher obtains material or data from second hands and it is not original data from the first data in the field. Fourth, the condition of the library data is not limited by space and time (Zed, 2003:4-5). Based on the aforementioned explanation, the data collection in the research is done by reviewing and/or exploring several journals, books, and documents (either in the form of print or electronic) as well as other sources of data and/or information, considering the links to the research or study.

\section{RESULTS AND DISCUSSION}

Understanding the foundation of philosophy is an activity carried out by using deep and thorough thinking to realize or to know all the causes and effects of truth. Philosophy can also be interpreted as a series of activities based on a question of belief, a person's concept of someone's attitude which will lead to the direction and goals that someone will take. Meanwhile, educational technology has been developed as an independent scientific discipline. The development of educational technology is in accordance with the direction of educational development. Educational technology is a scientific discipline that is in accordance with the rules of basic, which can be a benchmark for developing science. While the philosophical foundation is a foundation that is closely related to the meaning or nature of education.

Based on the review of philosophy, all knowledge has three components which are the main pillars for the supported knowledge, including the discipline of educational technology. The three main pillars are the ontological basis about what is knowledge, the epistemological about how knowledge is formed, and the axiological basis about why knowledge is used and its function.

Ontology is the main key in determining the scope of something that is the object of study and interpretation of the nature of the object itself. Epistemology is the way in which knowledge material is obtained and organized into a body of knowledge itself. And axiology is the main key in using the knowledge obtained and compiled in the body of knowledge itself. Hence, it can be said that ontology is a field of study of educational technology as a science, in order to determine the field of study. Based on the epistemology views, it is used to decide 
what approach employed to study educational technology. If it is viewed from the axiology, what values or its use do we get from educational technology in general and specifically, visually and abstractly.

\section{Ontology}

Ontology is the study of the ultimate reality, both physical/concrete and spiritual/abstract. Ontology departs from the investigation of the nature of existence (existence and being) (Brameld, 1955: 28). This ontology view will practically become a major problem in education because students get along with the world and they have a strong urge to understand something. Therefore, educational technology is part of development to facilitate the relationship of students or students with the world of their environment. Learners, whether in the community or at school, always face reality and objects of experiences.

Below are four revolutions that occurred in the world of education because of problems that were not resolved in the previous way, but it also leads to new problems. The problems are limited to the main problem, namely "learning". According to Sir Eric Ashby (1972, pp. 9-10) regarding the occurrence of four revolutions in the world of education, namely: 1) the first revolution happened when parents or families gave up some of their responsibilities and education to others who were specifically given the responsibility for it. In this first revolution, there were still cases where parents or families still carried out their own education for their children. From some literature, for example, Seattler tries to trace historically the development of this revolution by suggesting that the Sufis around $500 \mathrm{BC}$ made themselves "sellers of knowledge", that is, giving lessons to anyone who is willing to give them wages or rewards. This first revolution happened because parents/families were no longer able to teach their own children. 2) The second revolution occurred when the teacher is the person who is entrusted with the responsibility to educate. Teaching at that time was given verbally and meanwhile educational activities were institutionalized with various standardized provisions. The cause of this second revolution is because teachers want to give lessons to more students in a faster way. 3) The third revolution emerged with the invention of the printing press that allowed the distribution of iconic and numeric information in the form of books or other print media. Books until now are considered as the main media besides teachers for educational purposes. This revolution is still ongoing, even some philosophical views argue that a learning society is a reading society. Some experts state that education in Indonesia is still ongoing, the listening culture has not yet reached the reading culture. This third revolution occurs because teachers want to teach more and more quickly, while teachers' abilities are increasingly limited, so it is necessary to use the knowledge that has been formulated by others. 4) The fourth revolution took place with rapid developments in the field of electronics, the most prominent of which were communication media (radio, television, tape, etc.) which managed to penetrate geographical, social and political boundaries more intensely than print media. Messages can be faster, more varied and have the potential to be more useful to the recipient. In this revolution, a new concept of readability (literacy) emerged, which not only required an understanding of letters, numbers, words and sentences, but also a visual understanding. Some experts argue that the development of this communication media has made the world "shrink", becoming a "global village" where all the citizens know each other and they need each other. In this fourth revolution, what really stands out is increasingly sophisticated equipment. The cause of this revolution is because teachers realize that it is not possible for teachers to provide all the necessary teachings, and therefore it is more important to teach students how to learn. Future teachings will be obtained by the learner throughout his life through various sources and channels. 
Based on the causes and conditions of the development of the four revolutions that occurred in the world of education above, which focused on the main problem, namely "learning" can be simplified, namely at first the teacher faced his students face to face and the teacher acted as the only source for learning. Subsequent developments, teachers use other sources in the form of books written by other people, or it can be said that teachers share their roles in presenting teachings to other colleagues who present messages through books. In this situation, the teacher may still carry out his duties of selecting books and monitoring learning activities closely. In subsequent developments, communication media are able to channel messages designed by a separate team from the teacher, directly to students without being controlled by teachers.

In the development of the revolution, the purpose of education must determine what facilities are used. In other words, the communication media determines the message (and therefore the goal) that needs to be mastered. With the illustration above, it can be concluded that there are new problems, namely: the existence of various kinds of sources for learning including people (book authors, media procedures, etc.), messages (written in books or presented through media), media (books, television programs, radio etc.), tools (television networks, radio, etc.) certain ways of processing/presenting messages and the environment in which the educational process takes place. The need for these sources to be developed, both conceptually and factually. It is necessary to manage development activities, as well as learning resources so that they can be used optimally for learning purposes. The three points above are the scope of the object of study (ontology) of Educational Technology. An object that is not within the scope of another field of knowledge.

\section{Epistemology}

Epistemology, (from the Greek episteme (knowledge) and logos (word/talk/science) is a branch of philosophy that deals with the origin, nature, and types of knowledge. Epistemology or Theory of Knowledge deals with the nature of knowledge, assumptions, and basics of knowledge). Basis and responsibility for statements regarding the knowledge is possessed by every human being.

Epistemology, or theory of knowledge, deals in depth with all the processes involved in our pursuit of knowledge. Science is knowledge obtained through a certain process called the scientific method. This method distinguishes science from other ideas. In other words, science is knowledge obtained by applying scientific methods because science is part of knowledge, namely knowledge that has certain properties. Science can also be called scientific knowledge. For this purpose, in order to avoid confusion between the meanings of "science" and "knowledge", we use the term "science" for "science." (Jujun Suriasumantri. "About the Nature of Science: An Introduction to the Editor."

It has been described above that Educational Technology as a science. From here the question arises "how to get knowledge of Educational Technology?" According to Abdul Gafur (2007) is by: 1) Examining all learning problems simultaneously. 2) All situations are considered and studied in relation to each other, and not studied separately. 3) Systemically integration of development, production, utilization, management, and evaluation activities. 4) Designed, developed, assessed and managed as a unit, and aimed at solving problems. 5) Strive for synergism or interaction with the entire process of development and utilization of learning resources. Incorporation into a complex process and attention so that the symptoms as a whole must contain the power of folding or synergism, in contrast to the case where each function runs independently

M. Arif argues that epistemology (how) is the principle of how knowledge material is obtained and organized into a body of knowledge. There are 3 contents of the epistemological 
foundation of educational technology, namely: 1) all learning problems and their solutions are studied simultaneously. All existing situations are considered and studied in relation to each other rather than being studied separately. 2) the elements of interest are integrated in a complex process systematically that is designed, developed, assessed and managed as a whole, and it is aimed at solving problems. 3) Incorporation into a complex process and attention to symptoms as a whole, must contain a folding or synergism, in contrast to the case where each function runs independently.

\section{Axiology}

Axiology has many definitions, one of which is stated by Bramel that axiology consists of three parts, namely moral conduct, esthetic expression and socio-political life. Axiology must limit the neutrality without limits to science, in the sense that the neutrality of science is only limited to metaphysics of science, while its use must be based on moral values.

Today, the terms axios (value) and logos (theory) are more familiarly used in philosophical dialogue. So, axiology can be referred to as the theory of value or value theory. Part of philosophy that is concerned with good and bad (good and bad), right and wrong (right and wrong), and about means and ends (means and ends). Axiology tries to formulate a consistent theory for ethical behavior. He asked what is good (what is good?). When the good is identified, it allows one to talk about morality, namely using words or concepts such as "ought" or "ought" (ought / should). Thus axiology consists of the analysis of beliefs, decisions, and moral concepts in order to create or discover a theory of value.

There are 6 things that have potential uses in educational technology, namely: 1) Increasing education productivity, by employing: (Accelerating learning retention, helping teachers to use their time better, and reducing the burden on teachers in presenting information, so that teachers can foster and develop children's learning enthusiasm.) 2) Provide educational possibilities that are more individual in nature, by doing: (Reducing rigid and simple teacher control, giving children opportunities according to their abilities). 3) Provide a more scientific basis for teaching, with directions (planning a more systematic teaching program and developing teaching materials based on research on behavior). 4) More applying lessons, by increasing human capacity with various communication media. (Presenting information and data in a more concrete way and enabling learning more intimately, by way of) 5) reducing the gap between lessons inside and outside school, providing first-hand knowledge. 6) Enables the presentation of education more broadly and equitably, by way of jointly utilizing rare resources or events, presenting information across geographic boundaries.

According to Wijaya Kusumah in the study of axiology, namely what are the values / benefits of the study of educational technology that can be applied in several ways, including 1) Improving the quality of education (interesting, effective, efficient, relevant), 2) Completing the education system. 3) Widespread and equitable opportunities and access to education, 4) Adjustment to learning conditions, 5) Alignment with environmental developments, 6) Increased community participation

Meanwhile, M. Arif stated that Axiology (for what) is the principle in using the knowledge that has been obtained and compiled in the body of that knowledge. The justification or axiological basis of educational technology needs to be considered and discussed continuously because of the real needs that support its growth and development. According to him, the axiological foundations of current educational technology are: 1) the determination to expand and equalize learning opportunities. 2) The need to improve the quality of education in the form of, among others: 
Improving the curriculum, providing various educational facilities, and increasing the ability of teaching staff through various forms of education and training. 1) Improving the education system with research and development in accordance with the challenges of the times and development needs. 2) Increasing community participation by developing and utilizing various educational institutions and sources.

In this case, Technological tool of learning based on axiological aspect will make education: (Productive, Scientific, Individual, Simultaneous / Actual, Evenly, Highly absorbent). Educational Technology will also emphasize on the value that the convenience provided by the application of technology is not a goal, but a tool that is selected and a strategy for its use is designed to cultivate the nature of how to humanize technology (A.L Zachri: 2004).

\section{CONCLUSION}

The notion of the philosophical foundation. The philosophical foundation is a foundation that is closely related to the meaning or essence of education because philosophy tries to formulate an image of humans and society, while education itself tries to create an image. Philosophy also seeks to answer critically and fundamentally various basic questions about education. 2. Objects of philosophy. This branch of science includes: an ontology or formulation of a formal object or subject of study which is a symptom of observation that has not been explored by other fields of study; epistemology, namely an intellectual effort or principle to obtain the truth in the specified subject matter; Axiology is the values that determine the usefulness of the specified subject matter, which questions moral or ethical values and artistic values and beauty or aesthetics. 3. Objectives and Application of Philosophical Foundations in Education a. Objectives 1) Increase educational productivity 2) Enable more individualized education 3) Provide a more scientific basis for teaching 4) More solidify teaching 5) Enable more intimate learning 6) Enable wider and more equitable education delivery b. Applications of technology education include: 1) Integrating various approaches from the fields of psychology, communication, management, engineering, and others in a systematic manner. 2) Solving learning problems in humans thoroughly and simultaneously, by paying attention and studying all conditions and the interrelationships between them. 3) Using technology as a process and product to help solve learning problems. 4) The emergence of a folding power or synergy effect, where the combination of approaches and or elements has more value than just a sum. Likewise, comprehensive and simultaneous solutions will have more value than solving educational problems.

\section{REFERENCES}

Harjali. 2011. Teknologi Pendidikan. Ponorogo: STAIN Po PRESS

http://fadlibae.wordpress.com/2010/03/10/landasan-ilmiah-dan-penelitian-teknologipendidikan/

http://fakultasluarkampus.net/2007/07/apa-ontologi-teknologi-pendidikan/ 
Email : editorijhess@gmail.com

http://www.hariyono.org/2011/10/landasan-filosofis-teknologi-pendidikan.html

Penerbitan Universitas Negeri Jakarta.

Pidarta, Made. 2007. Landasan Pendidikan . Jakarta: Rineka Cipta.

ttp://unikharynizar.multiply.com/journal/item/5/Epistimologi_TP http://www.candilaras.co.cc/2008/05/dasar-dasar-filosofis-teknologi.html

Yusufhadi, Miarso. 2011. Menyemai Benih Teknologi Pendidikan. Jakarta:

Pustaka Diknas. Kencana. Seels, Barbara. B., Teknologi Pembelajaran Definisi dan Kawasannya. Jakarta: Unit.

Zed, Mestika. Metode Penelitian Literatur. Jakarta : Yayasan Obor Indonesia. 2003. 